manufacturers. There is an identity of interests between them: and until this great truth is fully understood and carried into operation, this country can never extricate itself from a situation, which has been thus justly characterized by the secretary of the treasury: 'Few examples have occurred, of a distress so general, and so severe, as that which has been exhibited in the United States.'”

\title{
A Rare Purchase
}

The George F. Baker Library has recently purchased a rare eighteenth-century volume, entitled $A$ Familiar Discourse or DIALOGUE Concerning the Mine-Adventure, which was printed by F. Collins in the Old-Bailey, London, 1700 . Though no author's name appears in our volume, Halkett \& Laing's Dictionary of Anonymous and Pseudonymous English Literature, on the authority of the Advocate's Library, Edinburgh, attributes the work to one William Shiers who was a shareholder in the venture.

This volume is an interesting and clever work that really must be read to be appreciated. The dialogue method is employed to great advantage and "Two Noble Lords, a Learned Doctor of Divinity, and an Eminent Merchant of London," discuss at great length the relative merits of the mine-adventure at Bwlchyr-Eskir-Hyr in South Wales. Though the preface states that the purpose of the book is to bring about a clear understanding of the works in question, and "A prudent Moderation between two Extreams," that is, between those who affirm that the mines are not worth working, and those who expect "a speedy return of Mountains of Treasure," the casual reader will no doubt gain the impression that the claims are rather extravagant, which is to be expected, since the book was published at the instigation of the committee in charge of the venture. Despite the biased character of the work, it is nevertheless particularly interesting from the standpoint of both the engineer and the economist, as the methods of raising ore are discussed in detail, as well as methods of bookkeeping, stock transfer, costs of production, a complete dissertation on "bulling" and "bearing" the market, and a general treatise on the theory of "balance of trade."

At the time the book was published in 1700 , the partners had been forced because of law suits, etc., to sell "lots" to the public in order to finance the project. The ethical aspects of such procedure 
are cleverly justified by the "Learned Doctor of Divinity" on the authority of the "Sacred Writ," and also on the grounds that a twelfth of the profits were appropriated to charitable uses.

The mines in question had eight veins, six of lead and two of copper. However, at that time (until greater quantities could be raised) they were selling lead in a powder form called Lytharge (lead monoxide). The boring was all done by hand with "sharp Chizels, skrew'd to Iron-rods, of about Four foot long, which are also skrew'd together to what length you please; with which we pounce the Rock into a Powder, and by continually turning about, we keep the Hole round." When the hole was choked a borer was used. Apparently when the shafts were bored gun powder was used to blast upwards. One of the Lords suggested the use of an engine, but the Merchant replied that Capt. Savory's fire engine had been considered but as it would cost about forty shillings a ton to raise the ore, and as it could be raised for 5 or 6 shillings a ton by hand, it was not considered feasible. It is interesting to note that miners employed by "bargain" were paid approximately thirty shillings a fathom, with the result that profits were calculated to amount to at least five pounds a ton. It was estimated that two men could raise one ton of ore per week and on the basis of forty working weeks per year, employing I,024 men, this meant that 20,480 tons would be a rational yearly product - which would yield a return in profits of half a million dollars per year! The Merchant had reached these amazing results after finding that all "Authors and experienced Miners do agree, with old Zienophon.... That our Gains will be greater or less in proportion to the number of hands we employ: And therefore if we can employ double the number of Hands, and consequently raise double the quantity of Oar, why can't we double our Profits?" As yet we were not in an age that was aware of the "law of diminishing returns!"

Calculations were then made as to the possible profits to be derived from extracting silver from the lead ore. As the profits to the company were estimated at but ten shillings to a ton of lead, it was pointed out that the nation's treasure would thereby be enriched by five pounds. This was the incentive for a conventional eighteenthcentury discourse on the theory of the "balance of trade." Subjoined is The Second ABSTRACT Of The State of the Mines of Brolchyr-Eskir-Hyr, and A LIST Of All The ADVENTURERS In The Mine-Adventure, in which appear many prominent names of the early part of the eighteenth century. 